\title{
PRAKTYKA I WLADZA SYMBOLICZNA U BOURDIEU: SPOJRZENIE Z BERKELEY ${ }^{1}$
}

\section{LOÏC WACQUANT I AKSU AKÇAOĞLU}

PRZEŁOŻYŁ TOMASZ WARCZOK

\begin{abstract}
Abstrakt: Aksu Akçaoğlu przebywał w latach 2014-2015 na Wydziale Socjologii Uniwersytetu Kalifornijskiego w Berkeley jako visiting scholar, gdzie wspólnie z Loikiem Wacquantem pracował na swym projektem poświęconym „habitusowi konserwatywnemu”. W poniższej rozmowie prosi Wacquanta o wyjaśnienie filozofii i pedagogiki jego słynnego seminarium prowadzonego w Berkeley, poświęconego Pierre'owi Bourdieu. Stanowi to okazję do przyjrzenia się raz jeszcze kluczowym węzłom konceptualnym w pracach Bourdieu, naświetlenie jego antyteoretycznej postawy, czy też rozwikłania relacji między przestrzenia społeczna, polem i władzą symboliczną oraz ostrzeżenia przed pokusami „bourdieziańskiej mowy".
\end{abstract}

Słowa kluczowe: Bourdieu, praktyka, przestrzeń społeczna, przemoc symboliczna, antyteoretyzm

\footnotetext{
1 Tekst jest tlumaczeniem artykułu „Practice and Symbolic Power in Bourdieu: The View from Berkeley” który ukazał się w The Journal of Classical Sociology 17, nr 1, 2017; opublikowane zostaną także tłumaczenia: tureckie (Modus Operandi), włoskie (Polis), duńskie (Praktiske Grunde), hiszpańskie (Herramientas), holenderskie (Socio-Logos) i niemieckie (Berliner Debate Initial).
} 


\section{Tematem tegorocznego „bourdierowskiego obozu rekrutów” w Berkeley jest Praktyka i władza symboliczna u Bourdieu. Dlaczego wybrałeś ten właśnie temat?}

Jest to ogólny temat dla SOC202B, cotygodniowego seminarium z teorii społecznej na poziomie zaawansowanym, któremu moi studenci nadali czule militarny przydomek, wynikający z oczekiwanej tam wyjątkowo intensywnej pracy: podczas tego przyspieszonego, wymagającego ogromnego poświęcenia programu musisz połknąć, przeżuć i przetrawić ogromny zakres pism Bourdieu, zorganizowanych historycznie i tematycznie, obejmujących pełny okres jego kariery; właściwie musisz przepracować piętnaście lat studiów metodologicznych w ciągu krótkich piętnastu tygodni. W chwili, w której zapisujesz się na ten kurs, zobowiązujesz się by przez 24 godziny na dobę, pięć dni w tygodniu, przez cztery miesiące, czytać, pisać, jeść, pić, spać, śnić, dyskutować i myśleć o Bourdieu. Chcąc uchwycić specyficzny mentalny modus operandi jakiekolwiek wielkiego myśliciela, czy to Bourdieu, czy Hanny Arendt czy Ibn Chalduna, musisz głęboko wejść w jego intelektualną siatkę i przejść od zaznajomienia przez obsesję, stopienie się z nią, aż do powrotu. Wymaga to pewnego poziomu celowego oddania się, które moje seminarium ma podtrzymywać. Zasadniczym celem nie jest jednak nawracanie cię (teoria społeczna to nie teologia), ale sprawienie, byś stał się biegły w szczególnym sposobie myślenia, który możesz później wykorzystać i zaadaptować do swoich własnych celów analitycznych.

Tytuł seminarium odnosi się do dwóch centralnych dla całej pracy badawczej Bourdieu węzłów konceptualnych. Pierwszym jest przejście od struktury do praktyki rozumianej jako wszystko, co ludzie robią, myślą bądź odczuwają w swej codziennej rzeczywistości. Powraca w nim na nowo świadomy, aktywny i doświadczony podmiot działający (jest to główne zadanie, jakie ma do spełnienia pojęcie habitusu, które Bourdieu odnalazł i zaczął udoskonalać w latach sześćdziesiątych), przy zachowaniu jednak relacyjnego sposobu myślenia, stanowiącego o sile ujęć strukturalistycznych w naukach społecznych od czasów Marksa, Durkheima i Freuda. Zabieg taki czyni z Bourdieu anty-strukturalistycznego strukturalistę. Książka, który sygnalizuje owo dialektyczne zerwanie ze strukturalizmem jest Zarys teorii praktyki (oryginalne wydanie 1972), będący jednocześnie oficjalnym wyjściem Bourdieu z cienia Claude'a Levi-Straussa (w kwestii relacji Bourdieu z papieżem neo-sausserańskiego strukturalizmu polecam monografię Antoine'a Lentackera La Science des institutions impures. Bourdieu critique de Lévi-Strauss, 2010).

Drugim węzłem jest idea, która - w moim przekonaniu - jest centralna dla Bourdieu i stanowi jego prawdziwie oryginalny pomysł: præ̧emoc symbolicz̧na, czyli zdolność do najbardziej istotnych kategoryzacji, możliwość tworzenia, zachowania i zmiany świata, realizowana poprzez kształtowanie i rozpowszechnianie ram symbolicznych - zbiorowych instrumentów poznawczego konstruowania rzeczywistości. Pojęcie to jest pojemniejsze, bardziej złożone, 
bardziej wielowymiarowe i potężniejsze niż habitus, kapitał, pole razem wzięte i podniesione do kwadratu (za każdym razem jestem - łagodnie rzecz ujmując - zakłopotany, kiedy napotykam „omówienia” Bourdieu, w których nawet nie wspomina się o tym pojęciu). Przemoc symboliczna jest zakotwiczeniem dla triady poznanie-uznanie-nierozpoznanie, która przedstawia aktora społecznego jako „zwierzę symboliczne” - by użyć tu języka Ernesta Cassirera, będącego głównym źródłem inspiracji dla Bourdieu w tym obszarze (tutaj kluczową książką jest majestatyczny Esej o człowieku. Wstęp do filozofii kultury, 1977) - jednocześnie jednak traktuje go jako ucieleśniony i zakorzeniony podmiot działający, istniejący od początku do końca w oczach innych poprzez powtarzającą się „grę luster”, w której społeczne fikcje staja się rzeczywistością o tyle, o ile opierają się na podzielanych kategoriach i wspólnych przekonaniach, ugruntowujących harmonijne działanie. W podobny sposób pojęcie kapitału symbolicznego wyraża myśl Bourdieu, że władza nigdy nie jest równie skuteczna (i niebezpieczna), kiedy się ukrywa i paradoksalnie zostaje uruchomiona przez zdominowanych, ponieważ funkcjonuje poprzez poznawczą relację zgody nieprzejrzystej dla niej samej, omijając stosowanie materialnej perswazji. Przemoc symboliczna jest takim rodzajem bezwysiłkowej siły, kształtującej świat poprzez komunikację, której nawet nie zauważamy; oszukuje ona zarówno dominujących, jak i zdominowanych, co pokazał Bourdieu w Meskiej dominacji (1998).

Władza symboliczna jest idea, którą Bourdieu rozwija przez całe swoje naukowe życie, od wczesnych badań nad honorem w Kabylii i pokrewieństwem w Béarn, poprzez prace poświęcone sztuce, edukacji i społecznemu cierpieniu, aż do jego ostatnich wycieczek w kierunku polityki i z powrotem do nauki jako takiej. Najbardziej zwięźle koncept ten wyrażony został w socjologicznej pragmatyce Ce que parler veut dire (1982b) oraz Medytacjach Pascaliańskich (1997). Najlepsza ilustracja zaś znalazła się w jego cyklu wykładów On the State (2012 [2015]), gdzie mówi on o „nadrzędnej władzy symbolicznej”, „ostatecznym fetyszu”, „rękojmi wszystkich fetyszy”. Zrozumienie tego pojęcia jest niekończącą się, ale radosną podróżą, jego opanowanie jest równoznaczne z uchwyceniem i opanowaniem całości pracy Bourdieu.

Opierając się na tym co powiedziałeś, mam przeczucie, że seminarium zostało tak zaprojektowane, by stworzyć społeczne warunki wytwarzania odrębnego socjologicznego habitusu. Pamiętam Twoje polecenia przekazane uczestnikom pierwszego dnia, wyłożone w potrójnym poleceniu „czytaj-pisz-dyskutuj” nieustannie, nie tylko podczas trzygodzinnego popołudniowego seminarium, ale także przygotowując pięciostronicowe notatki, którymi trzeba się było podzielić się z innymi przed każdym spotkaniem. Okazało się, że przez cały semestr te trzy aktywności misternie się ze sobą łączyły, na koniec zaś zawarte zostały w dossier, które trzeba było przygotować, by zaliczyć przedmiot. Czy możemy zatem pomówić o tworzeniu 


\section{socjologicznego habitusu, a jeżeli tak, to jaka miałaby być w tym procesie rola uniwersytetu, profesorów, studentów i samych zajęć?}

Twoja intuicja jest trafna: podczas tego seminarium staramy się, indywidualnie i zbiorowo, zwalczać wpisane w sytuacja akademicką scholastyczne skrzywienie, po to by wytworzyć dyspozycje generatywna wobec teorii rozumiana jako pragmatyczne sposoby tworzenie obiektów socjologicznych. Bourdieu jest myślicielem paradoksalnym, ponieważ pozostaje intuicyjnie i epistemologicznie antyteoretycznym teoretykiem spotecznym - intuicyjnie z powodu jego klasowego i etnicznego dorastania w wyizolowanej wiejskiej osadzie południowo-zachodniej Francji, świecie odległym od bezpiecznego doświadczenia skholé, w którym biesiaduja uczeni; epistemologicznie zaś wpłynął nań jego mentor, Georges Canguilhem, który podkreślał, że naukowy rozum rezyduje w samych historycznie ukonstytuowanych praktykach naukowców (kluczowym tekstem w tym względzie jest tajemnicze, ale odświeżające La Formation du concept de réflexe au 17 è au et 18 è siècle, 1955). Jest to trudne do zauważania, zrozumienia i przyswojenia, ponieważ stanowi zaprzeczenie tego, czego uczy nas szkoła: że teoretycy społeczni są specjalną i wyższą rasą oraz że umysły założycielskie dyscypliny tworzą stado tak zwanych „teoretyków”. Jesteśmy uczeni, by podchodzić do tekstów socjologów klasycznych Marksa, Durkheima, Webera, Simmla, Du Bois, czy kogokolwiek innego jak do świętych pism, którym należy się cześć i z przyzwyczajenia w taki sam sposób podchodzimy do Bourdieu. To jest kategoryczny błąd i ogromna przeszkoda w zrozumieniu jego prac. Właściwym sposobem podejścia do tekstu Bourdieu jest czytanie go jak „podręcznika instruktażowego”, tak aby sformułować inteligentne naukowe problemy i wykonać żmudną, własnoręczną pracę niezbędna, by rozwiązać je empirycznie.

Bourdieu upierał się, że nie „robi teorii”. Stale przestrzega nas przed pokusami czystych konceptualnych wywodów i niebezpieczeństwami „teoretyzowania”, które tak łatwo zbacza w stroną scholastyki (gdzieś w okolicach roku 1989 odrzucił zaproszenia Jeffreya Alexandra, apostoła neofunkcjonalizmu, by z Jürgenem Habermasem wziąć udział w czymś w rodzaju ,światowego szczytu” teorii społecznej, po prostu dlatego, że to zagadnienie nie miało dla niego żadnego sensu, nie wspominając już o osobach biorących w nim udział). A zatem nasze seminarium dąży raczej do zwrócenia uwagi na to, jak Bourdieu wykuwa i używa pojęć, co z nimi robi i do czego mu one stuz̧a niż w jaki sposób je definiuje i skąd je wywodzi. Znajomość trzynastu (a może jest ich dwadzieścia sześć?) różnych definicji habitusu, które można szybko zebrać z tekstów rozciąniętych przez prawie półwiecze, powie ci niewiele o tym kiedy, dlaczego i jak zastosować to pojęcie, by uruchomić genetyczny sposób myślenia, który się w nim zawiera (rozwinięcie tej kwestii można znaleźć moim tekście „Zwięzła genealogia i anatomia habitusu", 2016).

Podejście to tworzy nieuniknione napięcie w samym założeniu seminarium, ponieważ by owocnie czytać Bourdieu, tak jak każdego skomplikowanego i wielowymiarowego autora, 
musisz znać teksty - ich cele, zawartość, kompozycje, tło, odniesienia i wzajemne implikacje. W przypadku Bourdieu jest to szczególne wyzwanie. Po pierwsze dlatego, że jest on niezwykle samoświadomym i zdyscyplinowanym autorem, który w każdym swoim studium milcząco odnosi się do wyników niezliczonych innych, równolegle prowadzonych analiz (jego socjologia religii jest permanentnie niedostrzeganym punktem wyjścia dla jego socjologii sztuki, jego socjologia nauki stanowi bazę jego socjologii polityki itd.). Po drugie, kluczowe teksty Bourdieu zawsze pociagają za sobą ukryty dialog z filozofami, którzy go ukształtowali, zanim przeszedł na terytorium nauk społecznych: Dystynkeja jest cichą, ale brutalną korektą trzeciej krytyki sądzenia Kanta, podobnie jak zawoalowanym spotkaniem z Hume’em, którego Bourdieu czyta1 namiętnie podczas swojej młodzieńczej autostopowej podróży po Anglii (to, że filozofia Kanta, włączając w to jego etykę, estetykę i metafizykę wyrastała z frontalnej konfrontacji z Hume'em, zostało pokazane przez Paula Guyera (2008). Medytacje pascalianskie nie są wyłącznie ukłonem w stronę Husserla (i jego Medytacji kartezjańskich), ale poprzez niego także wobec niedualistycznego skrzydła siedemnastowiecznego racjonalizmu, zwłaszcza monizmu Spinozy i pluralizmu Leibniza, który Bourdieu sam rozwinął.

Musisz zatem zwrócić baczną uwagę na teksty, jednak bez fetyszyzowania słów autora, i praktykować rodzaj odwróconego czytania, podążając od konkretnych rezultatów i twierdzeń do projektu badań i działań, który leżą u ich podstaw, a wszystko to, by uchwycić sposób myślenia, który zszywa je razem. By móc to osiagnąć, czytamy wczesne i późniejsze analizy poświęcone tej samej kwestii (całość dzieła Bourdieu przeniknięta jest podobna strategią „powrotu i przeformułowania") oraz zestawiamy pisma abstrakcyjne z konkretnymi socjologicznymi eksperymentami. Na przykład, aby wyjaśnić pojęcie refleksyjności, czytamy lokalne rozwinięcie historycznego racjonalizmu jako epistemologii w działaniu, zawarte na pierwszych stu stronach The Craft of Sociology (1968), wespół z praktycznym testowaniem socjologicznego spojrzenia w pierwszym rozdziale Homo Academicus (1984, „Książka przeznaczona do spalenia”). Przed zanurzeniem się w rekonstrukcję historycznego wynalezienia estetycznego spojrzenia w Regutach sqtuki (1992 [2001]) zaglądamy do pilotażowego studium „Peasants and Photography” (1965), przeprowadzonego w rodzinnym Béarn Bourdieu, które posłużyło mu za wstępny test dla rozwinięcia krytyki uniwersalistycznego błędu kantowskiej estetyki.

Jest paradoksem używanie scholastycznego formatu do zwalczania scholastyki, jednak kiedy każdy odgrywa swoją część, zawzięcie zmagając się z materiałem, seminarium staje się pedagogiczną lokomotywa, niosąca ze sobą szyny, po których jedzie: rozwiązuje trudności, które samo wytwarza. Poza kwestiami szczegółowymi zawartymi w badaniach Bourdieu, pragnę kształtować bardziej ogólną postawę wobec socjologicznej pracy, której nauczyłem się od niego, a która najzwięźlej ujęta została w pojęciu epistemologicznej czujności Gastona Bachelarda (lub „intelektualnego superego trzeciego stopnia”, jak to przedstawił w swojej książce Le Rationalisme appliqué, 1949): miej świadomość, skąd wywodzą się problemy, sformuj swoje 
własne pytania, wykuj solidną analityczną konstrukcję, zamiast pożyczać nieostre i rozmyte pojęcia zdroworozsądkowe (włączając w to scholastyczny zdrowy rozsądek), metodycznie kwestionuj swoje metody i przyjmij proaktywna postawę, jeśli idzie o wytwarzania danych (zauważ, że nie mówię „zbieranie” danych, gdyż jest to jawny absurd: dane sa wytwarzane przez zadawanie ścisłych pytań w procesie przygotowywania projektu empirycznego; dane (datum) jako takie nie istnieją same przez się, nie są „zbierane” jak rozgwiazdy wyrzucone na brzeg). Nigdy nie akceptuj gotowego (prefabricated) obiektu: to pierwsze przykazanie, którego każdy socjolog winien przestrzegać.

A jeśli chodzi o rolę uniwersytetów - niestety, z chwilą kiedy zostały one przekształcone w „efektywne” fabryki umiejętności skrojone pod krótkoterminowe potrzeby rynku, działające pod presją nieustannych budżetowych oszczędności, stały się głównymi przeszkodami w wytwarzaniu i przekazywaniu naukowych dyspozycji. Szczególnie publiczne uniwersytety pozostaja obecnie wydmuszką tego, czym były zaledwie dwie dekady temu. Przeprowadzamy takie badania i nauczanie, jakie możemy - pomimo uniwersytetu, nie dzięki niemu. Podczas seminarium, w każdym przypadku, studenci biorą na siebie ciężka pracę, indywidualnie i zbiorowo. Prowadzenie seminarium jest jak dyrygowanie amatorską orkiestrą: gestykuluję, aby narzucić tempo, ale wytwarzanie socjologicznej muzyki należy już do samych uczestników.

\section{Dodatkowym wyzwaniem jest poradzeniem sobie z odmiennymi poziomami wiedzy} i oczekiwań uczestników, włączając w to uczonych i doktorantów takich jak ja, wywodzących się $z$ różnych krajów, którzy mają zróżnicowane, jeżeli nie przeciwstawne, wizje Bourdieu, ukształtowane przez odmienne narodowe sposoby recepcji jego prac.

Istotnie, seminarium przyciąga badaczy wywodzących się z różnych dyscyplin i kontynentów, którzy przybywają z własnymi gotowymi wiæjami Bourdieu, zazwyczaj poważnie zredukowanymi: Bourdieu, jak „teoretyk reprodukcji”, podczas gdy jego trzy pierwsze książki dotyczyły katastrofalnej transformacji kolonialnego społeczeństwa w stanie wojny; Bourdieu, który „ignoruje sprawczość”, podczas gdy celem koncepcji habitusu jest właśnie ponowne włączenie kreatywnego podmiotu działającego w samo serce analizy społecznej; Bourdieu, który „nie teoretyzuje powiązań między polami”, podczas gdy jedno z jego najbardziej charakterystycznych pojęć, pole władzy, zostało sformułowane, aby to właśnie uchwycić; lub Bourdieu, który jest „ślepy na kwestie etniczne”, podczas gdy szczegółowo opisywał kulturowe stopniowanie (dys)honoru i sam bym „etniczny” we francuskim społeczeństwie itd. A zatem turecki Bourdieu nie jest w tej kwestii Bourdieu brazylijskim, norweskim, ani francuskim : każdy kraj rozwija swoją własną, odrębną wersję dostosowaną do struktury i historii jego pola 
intelektualnego, wedle zasad sformułowanych przez Bourdieu w jego dyskusji nad społecznymi warunkami międzynarodowego krążenia idei (1990).

Bachelard uczy nas, że wiedza naukowa posuwa się naprzód nie poprzez wypełnianie tego co brakujące, ale poprzez zrywanie z „,wiedzą spontaniczną”, która jest zastana i nie ma tu żadnych różnic w odniesieniu do klasycznych prac socjologicznych przekraczających granice państw. Wystarczy kilka pierwszych spotkań seminaryjnych, by rozpędzić urojenia dotyczqce Bourdieu, które, paradoksalnie, są tym, co w pierwszym rzędzie przyciaga na to seminarium. Jest to zabawne i łatwe, jeżeli wobec jego pracy - traktowanej jako fakt społeczny i naukowy przyjmie się perspektywe genetyczna, do której nakłaniał w odniesieniu do jakiejkolwiek rzeczywistości społecznej.

Oprócz kartonowych obrazów trzeba także radzić sobie z silnymi emocjami, pozytywnymi lub negatywnymi, które Bourdieu zawsze wæbudza, a które dotyczą bądź badanych przez niego obiektów, ich proponowanych modeli, bądź generalnej intelektualnej postawy, którą prezentuje. Bourdieu posiada umiejętność wciagania czytelników głęboko w swe analizy, czy to przez analogię, czy homologie i sprawiania, że czują się w nie osobiście uwikłani. Jego socjologia jest socjoanaliza, w tym sensie, że odsłaniając rządząca nami wszystkimi, zdeponowaną w ciałach i instytucjach społeczną nieświadomość, umożliwia „powrót tego co stlumione" (jest to najbardziej widoczne w The Weight of the World [1992], oraz wiwisekcji Bourdieu trzech mikrokosmosmów, które go ukształtowały: wiejskiej społeczności Béarn, w której dorastał -Bachelors' Ball [2002]; systemu akademickiego, który go wychował, Homo Academicus, 1984; oraz instytucji filozoficznej, z która zerwał w The Political Ontology of Martin Heidegger [1988], pracy, która jest jednocześnie rodzajem egzorcyzmu filozofa, którym mógł się stać).

Taki powrót przynosi efekt w postaci objawienia, które może być uszczęśliwiające lub nawet wyzwalające: nie było niczym niezwykłym, że pod koniec wykładów publicznych ludzie podchodzili do Bourdieu, by podziękować mu za to, że zrywając zasłonę iluzji, w której żyli, diametralnie zmienił ich życie. Lecz jeśli nie jesteś przygotowany, może to być również obciążające lub duszące. Bourdieu sprawia, że ludzie skaczą z radości bądź zwijają się w sobie, krzyczą z bólu lub więdna; rzadko pozostawia ich obojętnymi. Jego pozornie najbardziej abstrakcyjne argumenty zawsze niosa jeźdźca de te fabula narratur Horacego, co wyjaśnia spolaryzowane reakcje, które wyzwala, zmierzając bądź w kierunku uwiedzenia, bądź odrzucenia i pozostawiając pomiędzy nimi niewielką przestrzeń. Zadaniem seminarium jest przejście od kłopotliwego „rozumienia przez serce” do racjonalnego ujęcia argumentacji, pojęć, których ona wymaga i epistemologicznych zasad, które są dlań podstawa.

Bourdieu jest szczególnie groźny dla tych uczonych, którzy maja satywne struktury mentalne i którzy pojmują analizę społeczną jako mechaniczne zastosowanie formuł zawartych we wszechogarniającym teoretycznym credo - na tym froncie ostatni marksiści twardo zmagaja 
się z ocalonymi Parsonistami (znakomity kolega z Berkeley, który brał udział w moim seminarium - i chciał w nim uczestniczyć raz jeszcze, ale nie mogłem się zgodzić - jeździ po świecie wygłaszając wykład o szalenie freudowskim tytule „Kto się boi Bourdieu?”). By uchwycić, a następnie zastosować tryb myślenia Bourdieu, musisz wyrzec się sakralizacji myślicieli i stać się kimś w rodzaju intelektualnego gimnastyka. Musisz nauczyć się wyginać i wykręcać w nietypowa, jeżeli nie niebezpieczna, pozycję teoretyczną: zestawić Marcela Maussa z Maxem Weberem, skrzyżować „ciało własne” Merleau-Ponty’ego z „człowiekiem neuronowym” Jean-Pierre’a Changeux, wrzucić Romana Jakobsona i Johna Austina razem, aby wiosłowali w jednej lingwistycznej łodzi, zanurzyć się w poważnej statystyce matematycznej, a jednocześnie wsłuchać się w społeczne intuicje zagnieżdżone w literackich innowacjach Virginii Woolf czy Thomasa Bernharda (dla ilustracji powyższego wystarczy zestawić wnikliwa, ilościową analizę „Conservative Revolution in Publishing” [1999] z autorefleksyjnym odczytaniem Emily Dickinson, w którym William Faulkner jest swego rodzaju literackim etnometodologiem, co zaprezentowano w Regułach sztuki, 1992). Bourdieu nigdy nie wstydził się zapożyczać pomysłów i twierdzeń z rozproszonych, jeżeli nie przeciwstawnych tradycji teoretycznych, ale w tym szaleństwie jest metoda: jego przewodni eklektyzm teoretyczny ograniczony jest przez twarde przywiązanie do tego, co nazywam „trzema R”: racjonalistyczna epistemologia, relacyjna ontologia i refleksyjna metodologia, która bez ustanku kwestionuje samą siebie, dokładnie w tym samym momencie, w którym jest stosowana.

Kiedy dasz już sobie radę z obrazami i emocjami, musisz jeszcze uporać się z kwestia języka Bourdieu. Tutaj pierwszą rzeczą, którą trzeba pokazać jest to, że idiolekt pojęciowy Bourdieu i jego spiralny styl są zastosowane celowo po to, aby zapobiec mieszaniu się pojęć potocznych i zdroworozsądkowego rozumowania z analityczna argumentacją. Druga rzecz trzeba wystrzegać się pokus bourdięiańskiej mowy: dzisiejsze czasopisma w całych naukach społecznych i humanistyce rozpętuja istne tsunami badań odwołujących się do Bourdieu, jednakże znacząca większość tych publikacji jedynie nakłada cienką warstewkę retoryki brzmiącej jak Bourdieu na projekt badań i ich wyniki, które nie maja żadnego związku z jego socjologia (prosty test, by rzecz zweryfikować: weź długopis i skreśl każdą wzmiankę o „habitusie, kapitale i polu”; jeżeli w wyniku ich usunięcia nic nie zostaje utracone, oznacza to, że powtarzanie ich w kółko nie wnosi nic poza uprawianiem chwilowej intelektualnej mody). A contrario, kiedy pojęcia Bourdieu i jego analityczne zasady są przewodnikiem dla konkretnych działań badawczych, natychmiast znajdujesz się w pozycji umożliwiającej wyartykułowanie nowych pytań i wymalowanie nowatorskiego krajobrazu empirycznego, tak jak to czyni Tom Medvetz w swoje modelowej analizie poświęconej powstaniu think-tanków w Ameryce (2012), przebijającej zasłonę badań nad elitami i polityka, by uchwycić wewnętrzną ambiwalencję tego organizacyjnego zwierzęcia i zdiagnozować jego niejasną rolę w amerykańskim polu władzy. 


\section{W przeciwieństwo do konwencjonalnej perspektywy postrzegania Bourdieu, bazującej} na triadzie „habitus, kapitał, pole”, Ty przedstawiasz duet „przestrzeń społeczna i władza symboliczna" jako pojęcia źródłowe, organizujące jego całe dzieło. Twierdzisz, że przesunięcie $\mathrm{z}$ triady $\mathrm{w}$ kierunku duetu nie tylko koryguje powszechne błędy, ale także rzuca światło na wewnętrzną logikę projektu Bourdieu. Możesz wyjaśnić z czym wiąże się owo przesunięcie?

W ciagu ostatnich trzech lat przygotowywałem nowe, rozszerzone, poprawione i uaktualnione wydanie Zaproszenia do socjologii refleksyjnej, ujmujące ostatnia, najbardziej płodną dekadę pracy Bourdieu (wynikało to z potrzeby powtórnego, całościowego przetłumaczenia tej książki na francuski, co zrealizowałem we współpracy z Etienne’em Ollionem). By to uczynić, przeczytałem masę rozproszonych, niejasnych, pozornie drugorzędnych tekstów Bourdieu, spośród których część nie jest nawet włączona do jego oficjalnej biografii, a które okazały się dawać nowy wgląd w jego intencje oraz wewnętrzną architekturę jego prac. Napisałem także rozszerzony esej przedstawiający dwie komplementarne ścieżki czytania całości dzieł Bourdieu, wszystkich siedmiuset prac. Pierwszą jest ścię̇ka genetycz̨na, odtwarzająca rozwój jego modelu w pięciu etapach; druga jest ścieǰka analitycżna wyjaśniająca proces tworzenia i cele siedmiu kluczowych pojęć (habitus, kapitał, pole, przestrzeń społeczna, władza symboliczna, doksa, refleksyjność), które stanowią podstawę specyficznego sposobu myślenia Bourdieu.

Drobiazgowa lektura transkrypcji jego seminariów i wykładów w Collège de France oraz tysiąca stron korespondencji, którą wymienialiśmy podczas przygotowywania Zaproszenia, a na którą mogłem teraz spojrzeć z analitycznego dystansu, całkowicie zmieniły moje rozumienie Bourdieu. To było jak zerwanie zasłony - o której nie wiedziałem nawet, że istnieje - umożliwiające odkrycie nowych punktów orientacyjnych, pozwalających żeglować przez ocean jego prac. Fundamentalny antyteoretyczny wymiar myśli Bourdieu ukazał mi się tak jasno jak nigdy przedtem; zasadniczy wpływ Cassirera stał się oczywisty (w obszarze epistemologii, w szkole marburskiej był on niemieckim strukturalnym odpowiednikiem Bachelarda); wyłoniło się także metodologiczne użycie jego rodzinnego Béarn jako eksperymentalnej podwaliny do testowania w miniaturze wielkich przedsięwzięć badawczych oraz wiele nowych elementów takich jak wielowymiarowy, wewnętrzny układ pola władzy i ukryta teoria rewolucji symbolicznych pojawiająca się w jego esejach poświęconych Flaubertowi, Heideggerowi, Baudelaire'owi, Beethovenowi i Manetowi.

Ale, co najważniejsze, stało się dla mnie jasne, że pržestrzeń społeczna jest kategoria macierzysta, koncepcją ogólną, z której logicznie wynika specyficz̨ne pojęcie pola jako wyspecjalizowanej przestrzeni społecznej, powstałej kiedy sfera działania i panowania (authority) staje się wystarczająco odgraniczona, zautonomizowana i zmonopolizowana. Uzmysłowienie sobie, że przestrzeń społeczna (a nie pole) jest konstrukcją generalną, która „zmusza” pojęcia 
habitusu i kapitału do generowania praktyk, wyjaśnia powracające trudności i rozwiązuje niezliczone fałszywe problemy. Po pierwsze, przypomina nam, że, patrząc historycznie, pola są stosunkowo rzadkimi zwierz̨tami, które istnieją wyłącznie w pewnych sferach działania i tylko w zaawansowanych formacjach społecznych, takich, które zostały poddane dostatecznej dyferencjacji - nie bez przyczyny Bourdieu odwoływał się nieustannie do Durkheimowskiego modelu spoteczeństw zróżnicowanych, a nie nowoczesnych, kapitalistycznych czy postindustrialnych (Craig Calhoun naświetlił wąską historyczność pól w jego przenikliwym tekście w tekście ze zbioru Bourdieu: Critical Perspectives, 1993, jednak widział w tym raczej nierozwiązywalne napięcie teorii praktyki, niż błędy w rozróżnianiu pola i przestrzeni społecznej). Przykładowo, nie ma pól w kolonialnej Algierii, gdyż formy kapitału nie są tam rozdzielone i uporządkowane w odrębne ścieżki instytucjonalne. Z tego właśnie powodu Bourdieu nie używa terminu pole w ponownej analizie swych wczesnych badań terenowych zamieszczonej w Zmyśle praktycznym (książka ta opublikowana została w 1980 roku, dekadę po przygotowaniu pełnego rozwinięciu teorii pola w artykule „Structure and Genesis of the Religious Field," 1971, które stanowi matrycę dla wszystkich innych pól).

Zdecydowana większość działań społecznych odbywa się w przestrzeniach społecznych, które tym właśnie są, przestrzeniami społecznymi, czyli wielowymiarowymi rozkładami społecznie efektywnych własności (kapitałów), określających zespół ustrukturyzowanych pozycji, na podstawie których przewidzieć można podejmowane strategie. Nie są one jednak polami, ponieważ nie posiadają zinstytucjonalizowanych granic, barier wejścia i specjalistów w budowaniu właściwych dlań źródeł autorytetu i socjodycei. Taka rewizja pozwala nam uniknąć komicznego mnożenia pól i form kapitału ad infinitum - niemalże nie ma miesiąca, by jakiś uczony nie zaproponował w tym względzie nowego gatunku. Nie istnieje zatem ,pole seksualne” (pace Eva Illouz [2016] i Adam Green [2013]), ani „,pole rasowe” (przepraszam Matta Desmonda and Mustafę Emirbayera [2015]), z tej prostej przyczyny, że ani seks, ani rasa jako zaprzeczona etniczność nie są zmonopolizowane przez sieć odrębnych instytucji i podmiotów działających, którzy rozwijaliby je na potrzeby konsumpcji przez innych, tak jak to czynią księża dla laikatu czy politycy wobec elektoratu. Istotnie, ich socjologiczne znaczenie wyraża się dokładnie w tym, że przecinają one mikrokosmosy i strukturyzują cała przestrzeń społeczną poprzez formowanie habitusu: są one zasadami postrzegania i podziału, nie uchwyconymi w polach. Patrząc szerzej, podkreślenia faktu, że przestrzeń społeczna stanowi kategorię zasadnicza jest zbieżne z przeformułowaniem, jakiego dokonał Bourdieu w kwestii tworzenia grup już po napisaniu Dystynk.ji (zarysowane tam ujęcie tego problemu uważał za niedopracowane i przestarzałe); porzucił mianowicie założenie o istnieniu klas, by utorować drogę dla radykalnej historycystycznej ontologii zbiorowości społecznych (w pełni argument ten rozwinąem w moim artykule „Symbolic Power and Group-Making: On Bourdieu's 
Reframing of Class," 2013, który odnosił się do wszystkich rodzajów grup - etnicznych, narodowych, religijnych, seksualnych itd.)

Zamieszanie wokół relacji pola i przestrzeni społecznej zostało częściowo spowodowane przez samego Bourdieu, i to na dwa sposoby. Po pierwsze, węższe pojęcie pola rozwiną on w latach 1968-1977, zanim opracowal w pełni szerszą kategorię przestrzeni społecznej, co miało miejsce między 1975 a 1985 i później. Nie może to zaskakiwać, zważywszy, że Bourdieu udoskonalał wszystkie swoje pojęcia na potrzeby poszczególnych badań empirycznych, przechodząc od jednego projektu do drugiego, zamiast budować pompatyczną Parsonowską metawizję, złożoną z przyjętego z góry zespołu kategorii analitycznych. Po drugie, Bourdieu musiał odkryć, nauczyć się i zaadaptować technikę wielokrotnej analizy korespondencji Jean-Paul'a Benzécri'ego, by zoperacjonalizować pojęcie przestrzeni społecznej i od tej pory używać go konceptualnie (przypadkowo wspominają o tym Leberon i Leroux w swoim tekście w pracy La Méthodologie de Pierre Bourdieu en action, 2015). Po trzecie, Bourdieu dość niedbale używał obu terminów, nawet po tym, kiedy wyklarował już pojęcie przestrzeni społecznej: czasem mówi o polu społecznym lub rodzinie jako polu, i różnych układach, które mieszają czystą przestrzeń społeczną z przecinającymi się wieloma polami, jako polach, którymi w rzeczywistości nie są. Stricto censu, można również sądzić, że tak zwane pole władzy tak naprawdę nie jest polem (nie stanowi miejsca koncentracji i dystrybucji odrębnego typu kapitału, nie posiada specyficznego nomosu, nie skrywa także żadnego zespołu odrębnych konstrukcji poznawczych itd.), pozostaje wszelako metapolem, rozumianym jako rodzaj wielowymiarowej przestrzeni społecznej.

Jeśli chodzi o triadę „habitus, kapitał, pole”, łatwo wykazać, że stanowi ona w najlepszym razie niespójną i niekompletną kondensacje myśli Bourdieu (pomimo tego, że Bourdieu używał jej czasem dla ściśle pedagogicznych celów): zestawianie kapitału i pola jest zbyteczne, ponieważ pole nie jest niczym więcej niż przestrzenią koncentracji kapitału; habitus jako taki jest ucieleśnionym kapitałem i z innego punktu widzenia może być rozumiany jako somatyzacja kategorii poznawczych i katektycznych, czyli jako wdrukowanie władzy symbolicznej w uspołeczniony organizm. Jeżeli do modelu Bourdieu zastosować semantyczny odpowiednik analizy najmniejszej przestrzeni a la Guttman i Lingoes, dojdziemy do wniosku, że duet przestrzeń społeczna i władza symboliczna wystarcza, by odtworzyć wszystkie inne używane przez niego pojęcia i od tej pory móc uchwycić wszelkie sensy zjawisk. Wyartykułowanie tego duetu tworzy oszczędny i nieredukowalny trzon konceptualny teorii praktyki Bourdieu. Dlatego taki właśnie będzie tytuł kolejnego seminarium „obozu rekrutów Bourdieu” w Berkeley.

Jesteś jednym z redaktorów ostatniej książki Bourdieu On the State ([2012]2015). Na specjalnym sympozjum zorganizowanym przez Wydział Socjologii Uniwersytetu 


\section{w Berkeley w marcu 2015, a poświęconym wydaniu angielskiego tłumaczenia tej książki, wskazałeś na związki między tą pracą a klasycznymi dziełami Marksa, Durkheima i Webera. Czy możesz powiedzieć, co czyni tę książkę wyjątkową?}

Po pierwsze, mała korekta: nie byłem jednym z redaktorów opublikowanego kursu z Collège de France poświęconego państwu. Redaktorem prowadzącym był ostatni doktorant Bourdieu, Franck Poupeau, który został zaproszony do Berkeley, by rozpoczać wspomniane przez Ciebie sympozjum, dlatego właśnie, że przewodził zespołowi starszych współpracowników Bourdieu, którzy obdarzyli go zaufaniem, powierzając to trudne zadanie. Wszelako poświęciłem pięć miesięcy nieustannej pracy, analizując linijka po linijce tysiące stron przedostatniej wersji tekstu i zarekomendowałem głębokie zmiany całości (skróty, przeróbki, objaśnienia terminologiczne, dodane przypisy i bibliografia itd.), które w większości włączone zostały do ostatecznego tekstu. Zespół paryski zdawał się być bliżej słowa mówionego, prezentując postawę redaktorskiego szacunku wobec mistrza. Miałem przywilej pisania z Bourdieu i doświadczenia zmieniającej się z nim relacji, inaczej niż jego starsi, niegdysiejsi studenci. Daje mi to rodzaj redaktorskiej zuchwatości, której oni, z powodów czysto socjologicznych, nie moga mieć, a co ostatecznie nadaje całej pracy niezbędną równowagę.

O dziwo, miałem bliższy związek z narodzinami tego cyklu wykładów. Na wiosnę 1986 w Chicago, gdzie rozpoczynałem swoje studia doktoranckie, zatrzymał się Bourdieu, wracając z San Diego po spotkaniu ze swoim przyjacialem Aronem Cicourelem, który wcześniej zaprosił go do Princeton, by dał tam wykład gościny na temat krytyki. Skończyłem właśnie poprawiać krytyczny ogląd jego dzieła, zestawiając „Lecture on the Lecture” (1982) wykład inauguracyjny wygłoszony po otrzymaniu przez Bourdieu stanowiska w Collège de France - ze znakomitą monografią jednego z jego doktorantów, Sylvaina Maresca, pokazująca, jak Les Dirigeants paysans (1984), „przywódcy rolniczych związków zawodowych”, przebudowali powojenne granice chłopstwa i poprzez pracę symboliczna, wykonaną wespół z państwowymi menadżerami, dokonali materialnych zmian tej grupy. Był to rodzaj ćwiczenia nad przykładem paradygmatycznym (w rozumieniu Thomasa Kuhna), do których Bourdieu zachęcił mnie kilka lat wcześniej, kiedy mieszkałem i pracowałem w Nowej Kaledonii - dlatego właśnie mój artykuł ostatecznie ukazał się w australijskim czasopiśmie! Uważnie przeczytał ten tekst i poczuł się urażony krytyką, którą rozwinąłem na końcu, nakłoniony przez moich chicagowskich profesorów Johna Comaroffa i Jamesa Colemana. Chodziło szczególnie o moje skupienie się na jego „rażącej ślepocie na kwestię państwa”. Moja trzecia krytyka przebiegała następująco:

„Trzeba wyrazić zaniepokojenie nad teoretycznym lekceważeniem roli państwa, charakteryzującym koncepcje przestrzeni społecznej Bourdieu. Fakt że nie istnieje ono 
w indeksach jego trzech najważniejszych prac (Bourdieu 1972; 1979a; 1980a) pokazuje, że państwo jest w rażący sposób nieobecne u Bourdieu. Ostanie wysiłki, by zaradzić temu problemowi i umiejscowić państwo w samym sercu teorii władzy symbolicznej doprowadzaja do jego (re)definicji jako »podmiotu, który posiada władzę prawomocnego nazywania, czyli władzę umożliwiającą oficjalne narzucanie prawomocnej wizji świata społecznego«" (Bourdieu, 1984, 118).

Jednakże zdefiniowanie pojęcia nie jest dowodem jego analitycznego potencjału i pozostaje wykazać, na ile Bourdieu jest zdolny wyjść z tak ograniczonej definicji, która ostatecznie zamyka go dokładnie w takiej subiektywistycznej pozycji, którą sam odrzuca: sprowadzania relacji dominacji do czystej relacji znaczeń. Francuski teoretyk społeczny wyszedłby, jak sądzę, poza kwestie nominacji i klasyfikacji, gdyby jego schemat odniósł się w sposób zasadniczy do analizy klasowej. Jeśli idzie o państwo, to czyni ono znacznie więcej niż tylko to, że przydziela tytuły i narzuca taksonomie: kieruje również gigantyczną siecią pomostów między polami (prawnymi, politycznymi, ekonomicznymi, społecznymi, kulturowymi), których granice, bariery wejścia i specyficzne stawki moga być łatwo zmienione pod wpływem siły, jeżeli tylko zajdzie taka potrzeba, co oznacza, że rzecz głęboko oddziałuje na strukturację klas społecznych. Powstaje zatem pytanie, czy państwo stanowi rodzaj kapitału sui generis i czy państwowe instytucje rozumiane jako pole różnią się znacząco od innych pól (Wacquant 1987, 79-80).

W Chicago Bourdieu odrzucił tę krytykę jako powierzchowną, upierając się, że państwo jest jednostką zbyt złożoną i wiekowa, by można ją było uchwycić frontalnie. Ponadto był to wówczas modny temat; rok wcześniej, dzięki wysiłkom Social Science Research Council opublikowano efektowna pracę zbiorowa pod redakcja Petera Evansa, Dietricha Rueschemeyera i Thedy Skocpol, Bringing the State Back In (1985), importująca do Stanów Zjednoczonych teoretyczną fascynację państwem, charakteryzująca europejskich neomarksistów lat siedemdziesiątych, takich jak Nicos Poulantzas, Claus Offe i Perry Anderson - oraz althusserianistów, od których odpychało Bourdieu! Ale kilka dni po jego wyjeździe otrzymałem zaskakujący telefon z Princeton, w którym stanowczo przyznał: „Tak, miałeś rację, by odpowiedzieć na Twoja krytykę, mój następny kurs w Collège de France poświęcę państwu”. Po spędzeniu trzech kolejnych letnich wakacji na intensywnym czytaniu i ostatecznym odnalezieniu empirycznego punktu zawieszenia swojej analizy, czyli politycznych ram wytwarzania i nabywania domów jednorodzinnych (skutkiem czego był raport dla Caisse des Dépots et Consignation, agencji państwowej finansującej budownictwo mieszkaniowe we Francji, a później podwójny numer Actes de la recherche en sciences sociales [1990], przekształcony następnie w monografie The Social Structures of the Economy, [2000]), Bourdieu podjal temat państwa, nigdy już go nie porzucając. 
To przesunięcie zostało podkreślone w końcu książki poświęconej roli elitarnych szkół w reprodukcji pola władzy, do której Bourdieu dodał rozszerzoną dyskusję zamykająca - „Władza państwa i władza nad państwem” i której tytuł zamienił w ostatniej chwili ze „szkolnej szlachty” na „szlachtę państwa”. Zabieg taki doprecyzowuje, że edukacja jest głównym mechanizmem wpajania państwowych kategorii myślenia (podczas gdy w swojej pracy z lat sześćdziesiątych dotyczącej edukacji Bourdieu w zastanawiający sposób præecinstawiat szkołę państwu). Pokazuje to także, że państwo jest równocześnie miejscem, celem oraz sędzią walk o kształt rzeczywistości. Zwrócenie się ku państwu wynikało także z intensywnej, trwającej całą tę dekadę, koncentracji Bourdieu na kwestii władzy symbolicznej, co w logiczny sposób popchnęło go do zmierzeniu się z wielkim „symbolicznym alchemikiem” ery nowoczesnej. Możesz na przykład zauważyć, że w otwierającym Ce que parler veut dire (1982) rozdziale historycznym, poświęconym narzuconej przez władze polityczne unifikacji lingwistycznej we Francji, Bourdieu pokazuje, że „produkcja i reprodukcja języka prawomocnego" idzie w parze z budową scentralizowanego państwa, na początku formowanego przez królewską władzę absolutystyczna, później przez republikańską burżuazję, której władza coraz bardziej opiera się na transmisji kapitału kulturowego potwierdzanego przez państwo, czyli na dyplomach szkolnych.

Dość powiedzieć, że Bourdieu był skłonny do uderzenia w Lewiatana raczej wcześniej niż później. A jednak to zabawne czytać dziś moją niezręcznie sformułowaną, młodzieńczą krytykę z 1986 roku i uzmysłowić sobie, że była tematycznie trafna i odegrała niewielka rolę w przyspieszeniu „coming outu” Bourdieu w tej kwestii (później podczas długich letnich miesięcy intensywnego czytania w swojej rodzinnej wiosce Béarn Bourdieu mógł żartobliwie narzekać: „niech cię cholera, przez ciebie wszedłem na minę przyswajając na okragło teorie państwa i nie ma w tym nic zabawnego"). Aż do kursu w Collège de France, państwo zdawało się być jakby nieobecnie obecne w rdzeniu prac Bourdieu - od rekapitulacji grabieży ziemi podczas tworzenia kolonialnego społeczeństwa w Sociologie de l'Algérie (1958), przez socjologię szkolnictwa (1964, 1970,1989), aż do badań z wczesnych lat dziewięćdziesiątych poświęconych społecznemu cierpieniu spowodowanemu przez ekspansję zasady rynkowej, z punktem kulminacyjnym w postaci ponownego zaangażowania się Bourdieu w debatę obywatelską.

Co sprawia, że On the State jest naprawdę wyjątkowym tekstem, najbardziej niezwykła praca z zakresu nauk społecznych, jaką kiedykolwiek czytałem? Łączy świeżość i zuchwałość Die Grundrisse Marksa (jest to śmiała, tymczasowa konstrukcja pierwszych zasad, która ma być udoskonalona), głębię i wigor Elementarnych form ṡycia religijnego Durkheima (państwo okazuje się być gigantyczna „maszyną klasyfikująca” i „kawałem kościoła zwróconego przeciwko sobie”: jak można być bardziej Durkheimowskim?), zasięg i ambicję weberowskiej socjologii religii (budowa typów idealnych rozciaga się na przestrzeni ośmiu wieków i trzech kontynentów). Ale trzeba do tego dodać, że jest to nieugięte, rozumne i wniklinve badanie samej ambicji $i$ aktu 
socjologicznego badania, co jest znakiem rozpoznawczym Bourdieu. W tym kursie autor Dystynkcji oferuje wnikliwą analizę różnych teorii państwa (czego nie robił z żadnym innym tematem) i odważną reinterpretację historycznej transformacji od „dworu królewskiego” do „rozumu państwowego”. Pokazuje także nowy model państwa jako zorganizowanej władzy uchwyconej w pojęciu pola biurokratycznego i idei „monopolizacji prawomocnej przemocy symbolicznej”. Dodatkowo zestawia wykuwanie nowoczesnego Lewiatana, opartego na biurokratycznym sposobie reprodukcji, z wymyśleniem tego, co publiczne - równocześnie dziejącym się, postępującym prywatnym przejmowaniem uniwersalnego oraz powstaniem kapitału kulturowego. Analiza ta ma klasyczny zasięg, zakres i głębię.

Książka, która winna nosić tytuł Wynaleqienie państwa (wyrażenie to wraca wielokrotnie podczas wykładów, a zamykający fragment The State Nobility, który jest przerobionym fragmentem wczesnego szkicu wykładów z Collège de France, zatytułowano „Szlachta i wynalezienie państwa”) ewidentnie nie jest pozycją, która mogłaby być wydana za życia Bourdieu. W przeciwieństwie do zapewnień redaktorów zawartych w posłowiu, Bourdieu nie planował napisania tomu o państwie. Tym, co powstrzymało go przed zrobieniem tego gdzieś w okolicach 1995 roku była niemożność wymyślenia, jak zorganizować i ulokować tę pracę w szerszym, kilkutomowym studium, które przygotowywał, a które poświęcone miało być ogólnej teorii pól, roboczo zatytułowanej Mikrokosmosy. Ale bądźmy zadowoleni, że tego nie uczynił, ponieważ tak wiele możemy nauczyć się z notatek przeznaczonych do wygłoszenia, które nie stały się ksiażka. Jest to niedokończony, surowy, pełny ostrych krawędzi i żartobliwych sformułowań tekst, zawierający olśniewające wskazówki, analityczne elipsy i kwestie nierozwiązane, przepełniony udręczoną szczerością wymagań odnoszących się do epistemicznych i praktycznych trudności socjologicznego fachu. Nie jest to skończony produkt, opus operatum państwa, ale zatrzymany ruch tworzenia, żywy modus operandi Bourdieu, drobiazgowo konstruującego swój prawdopodobnie najbardziej wymagający obiekt. I, jak twierdzę, jest to najlepszy sposób, by uchwycić jego socjologiczny motor w nieustannym pędzie. 


\section{Wykaz literatury}

Bachelard, Gaston. 1949. Le Rationalisme appliqué. Paris: Presses Universitaires de France. Bourdieu, Pierre. 1958. Sociologie de l'Algérie. Paris: Presses Universitaires de France. Bourdieu, Pierre. [1968] 1991. The Craft of Sociology. Tłum. R. Nice. New York: Walter De Gruyter.

Bourdieu, Pierre. [1971] 1991. „, Genesis and Structure of the Religious Field”. Tłum. J. B. Burnside. Comparative Social Research 13: 1-44.

Bourdieu, Pierre. [1972] 2007. Szkic teorii praktyki, poprzedzony trzema studiami na temat etnologii Kabylów. Tłum. W. Kroker, E. Klekot. Kęty: Wydawnictwo Marek Derewiecki.

Bourdieu, Pierre. [1979] 2005. Dystynkeja. Społeczna krytyka władsy sqdzenia. Tłum. P. Biłos. Warszawa: Scholar.

Bourdieu, Pierre. [1980] 2008. Zmyst praktyczny .Tłum. M. Falski. Kraków: Wydawnictwo UJ. Bourdieu, Pierre. 1982a. Leçon sur la leçon. Paris: Minuit.

Bourdieu, Pierre. 1982b. Ce que parler veut dire. L'économie des échanges linguistiques. Paris: Fayard. Bourdieu, Pierre. [1984] 1988. Homo Academicus. Tłum. P. Collier. Cambridge: Polity Press. Bourdieu, Pierre. [1988] 1994. The Political Ontology of Martin Heidegger. Tłum. P. Collier. Cambridge: Polity Press.

Bourdieu, Pierre. [1989] 1996. The State Nobility: Elite Schools in the Field of Power. Tłum. L. C. Clough. Cambridge: Polity Press.

Bourdieu, Pierre. [1990] 1999. „The Social Conditions of the International Circulation of Ideas". W Richard Shusterman, red. Bourdieu: A Critical Reader. Oxford: Basil Blackwell: $220-228$.

Bourdieu, Pierre. [1992] 2001. Reguły sұtuki. Geneza i struktura pola literackiego. Tłum. A. Zawadzki. Kraków: Universitas.

Bourdieu, Pierre. [1997] 2006. Medytacje pascalianskie. Tłum. K. Wakar. Warszawa: Oficyna Naukowa.

Bourdieu, Pierre. [1998] 2004. Meska dominacja. Tłum. L. Kopciewicz. Warszawa: Oficyna Naukowa.

Bourdieu, Pierre. [1999] 2008. „A Conservative Revolution in Publishing”. Translation Studies 1, nr 2: 123-153.

Bourdieu, Pierre. [2000] 2005. The Social Structures of Economy. Tłum. C. Turner. Cambridge: Polity Press.

Bourdieu, Pierre. [2002] 2006. The Bachelors' Ball. Tłum. R. Nice. Cambridge: Polity Press.

Bourdieu, Pierre. [2012] 2015. On the State. Tłum. D. Fernbach. Cambridge: Polity Press.

Bourdieu, Pierre i Jean-Claude Passeron. [1964] 1979. The Inheritors: French Students and Their Relation to Culture. Tłum. R. Nice. Chicago: The University of Chicago Press.

Bourdieu, Pierre i Jean-Claude Passeron. [ [1970] 2012. Reprodukcja. Elementy teorii system nauczania. Tłum. E. Neyman. Warszawa: PWN.

Bourdieu, Pierre i Marie-Claire Bourdieu. [1965] 2004. „Peasant and Photography”. Ethnography 5-4: 601-616.

Bourdieu, Pierre i in. 1990. „L'économie de la maison”. Actes de la recherche en sciences sociales, 81- 82.

Bourdieu, Pierre i Wacquant, Loïc. 2001. Zaproszenie do socjologï refleksyjnej. Tłum. A. Sawisz. Warszawa: Oficyna Naukowa. 
Calhoun, Craig. 1993. „Habitus, Field, and Capital: The Question of Historical Specificity”. W Bourdieu: Critical Perspectives, red. Craig Calhoun, Edward LiPuma, Moishe Postone. Chicago: The University of Chicago Press.

Canguilhem, Georges. 1955. La Formation du concept de réflexe au 17è au et 18è Siècle, Paris: Vrin.

Cassirer, Ernst. 1977. Esej o człowieku. Wstęp do filozofii kultury. Tłum. A. Staniewska, B. Suchodolski. Warszawa: Czytelnik.

Desmond, Matthew i Mustafa Emirbayer. 2015. The Racial Order. Chicago: The University of Chicago Press.

Evans, Peter B., Dietrich Rueschemeyer, i Theda Skocpol, red. 1985. Bringing the State Back In. Cambridge: Cambridge University Press.

Illouz, Eva. 2016. Dlaczego miłość rani. Studium z socjologii. Tłum. M. Filipczuk. Warszawa: Wydawnictwo Krytyki Politycznej.

Green, I. Adam. 2013. Sexual Fields: Toward a Sociology of Collective Sexual Life. Chicago: The University of Chicago Press.

Guyer, Paul. 2008. Knowledge, Reason, and Taste: Kant's Response to Hume, Princeton: Princeton University Press.

Lebaron, Frédéric i Brigitte LeRoux, red. 2015. La Méthodologie de Pierre Bourdieu en action. Espace culturel, espace social et analyse des données. Paris: Dunod.

Lentacker, Antoine. 2010. La Science des institutions impures. Bourdieu critique de Lévi-Strauss. Paris: Raison d'agir Éditions.

Maresca, Sylvain. 1983. Les Dirigeants paysans. Paris: Minuit.

Medvez, Tom. 2012. Think Tanks in America. Chicago: University of Chicago Press.

Wacquant, Loïc. 1987. „, Symbolic Violence and the Making of the French Agriculturalist: An Enquiry into Pierre Bourdieu's Sociology". The Australian \& New Zealand Journal of Sociology 23-1: 65-88.

Wacquant, Loïc. 2013. „, Symbolic Power and Group-Making: On Pierre Bourdieu's Reframing of Class". Journal of Classical Sociology 13-2 (May): 274-291.

Wacquant, Loïc. 2016. „Zwięzła genealogia i anatomia habitusu”. Tłum. T. Warczok. Praktyka Teoretyczna 3 (21): 163-173. 
Aksu Akçaoğlu - asystent i doktorant na Wydziale Socjologii, Middle East Technical University w Ankarze. Jego zainteresowania naukowe obejmują kwestie przestrzeni miejskiej i konsumpcji, zróżnicowania społecznego i władzy oraz polityki konserwatywnej i teorii społecznej. Jego dysertacja doktorska nosi tytuł The Conservative Habitus: The Quest for a New Social Space in Contemporary Turkey.

Loïc Wacquant - profesor socjologii na Uniwersytecie Kalifornijskim w Berkeley oraz pracownik naukowy w Centre de sociologie européenne w Paryżu. Jego zainteresowania obejmuja problematykę marginalizacji miejskiej, polityki karania, cielesności i teorii społecznej. Jest laureatem prestiżowej nagrody MacArthur Prize Fellow, jego książki przetłumaczono na ponad dwadzieścia języków, między innymi Body and Soul: Notebooks of An Apprentice Boxer (2004, nowe rozszerzone wydanie, 2016), The Two Faces of the Ghetto (2016), and Tracking the Penal State (2016). Więcej informacji znaleźć można na stronie domowej: loicwacquant.net.

\section{DANE ADRESOWE:}

Loïc Wacquant

Department of Sociology

University of California, Berkeley

Berkeley, CA 94720, USA

EMAIL: loic@berkeley.edu

CYTOWANIE: Wacquant. Loic i Aksu Akçaoğlu. 2016. Praktyka i władza symboliczna u Bourdieu: spojrzenie z Berkeley. Praktyka Teoretyczna 3 (21): 174-191.

DOI: $10.14746 /$ prt.2016.3.8

AUTHOR: Loïc Wacquant, Aksu Akçaoğlu

TITLE: Practice and Symbolic Power in Bourdieu: The View from Berkeley

ABSTRACT: In 2014-2015, Aksu Akçaoğlu was a visiting scholar in the Department of Sociology at the University of California, Berkeley, where he had come to work with Loïc Wacquant on his research on "the conservative habitus" in contemporary Turkey (with the support of the TÜBİTAK Science Program). In this dialogue, he invites Wacquant to explicate the philosophy and pedagogy of his celebrated Berkeley seminar on Pierre Bourdieu. This provides an opportunity to revisit key conceptual nodes in Bourdieu's work, to spotlight its antitheoreticist cast as well as the influences of Bachelard and Cassirer; to clarify the relationships between social space, field, and symbolic power; and to warn against the seductions of "speaking Bourdieuese."

KEYWORDS: Bourdieu, practice, social space, symbolic power, anti-theoreticism, epistemological vigilance, the state as supreme fetish, research pedagogy 